\title{
Comparison between resting metabolic rate and indirect calorimetry in postmenopausal women
}

\author{
Comparação de equações preditivas de taxa \\ metabólica de repouso com calorimetria \\ indireta em mulheres pós-menopáusicas
}

Randhall Bruce CARTERI ${ }^{1,2}$

Marceli FELDMANN²

Júlia Silveira GROSS²

Renata Lopes KRUGER²

André Luis LOPES 2

Álvaro REISCHAK-OLIVEIRA²

\section{A B S T R ACT}

\section{Objective}

To compare resting metabolic rate values determined by indirect calorimetry with values estimated using different predictive equations in lean and overweight postmenopausal women.

\section{Methods}

Twenty-four women, who had stopped menstruating for at least two years, were subjected to anthropometric measurements and indirect calorimetry after 12-hour overnight fasting to determine, mathematically and experimentally, resting metabolic rate values.

\section{Results}

There was no difference in the indirect calorimetry values between the groups evaluated. Difference values of resting metabolic rate were obtained with all equations used. For the lean women, there was no difference between the values obtained by indirect calorimetry and those estimated using the equations proposed by Food and Agricultural Organization, Fredix, Lazzer, and Schofield. However, in the overweight group, the resting metabolic rate values estimated using the Institute of Medicine, Berstein and Owen equations were different from those obtained by indirect calorimetry.

\footnotetext{
1 Universidade Federal do Rio Grande do Sul, Instituto de Ciências Básicas da Saúde, Departamento de Bioquímica. R. Ramiro Barcelos, 2600, 90035-003, Porto Alegre, RS, Brasil. Correspondência para/Correspondence to: RB CARTERI. E-mail: $<$ rcarteri@outlook.com>.

2 Universidade Federal do Rio Grande do Sul, Escola de Educação Física, Laboratório de Pesquisa do Exercício. Porto Alegre, RS, Brasil.
} 


\section{Conclusion}

This study suggests that differences in body composition in postmenopausal women influence the accuracy of predictive equations, demonstrating the need for more accurate estimation methods for resting metabolic rate in postmenopausal women with different body compositions.

Keywords: Basal metabolism. Calorimetry indirect. Menopause.

\section{RE S U M O}

\section{Objetivo}

Comparar os valores de taxa metabólica de repouso determinados por calorimetria indireta com os valores obtidos utilizando diferentes equações preditivas em mulheres pós-menopausicas eutróficas e com sobrepeso.

\section{Métodos}

Vinte e quatro mulheres com pelo menos dois anos de menopausa foram submetidas à avaliações antropométricas e à calorimetria indireta após 12 horas de jejum para determinar, matematicamente e experimentalmente, a taxa metabólica de repouso.

\section{Resultados}

Os valores para calorimetria indireta não diferiram entre os grupos e a taxa metabólica de repouso predita por equações foi diferente para todas as equações usadas. Para o grupo de eutróficas, as equações que não foram estatisticamente diferentes da calorimetria indireta foram Food and Agricultural Organization, Fredix, Lazzer e Schofield. No entanto, apenas as equações Berstein e Owen foram significativamente diferentes comparadas com calorimetria indireta para o grupo sobrepeso.

\section{Conclusão}

O presente estudo sugere que diferenças na composição corporal em mulheres na pós-menopausa modificam a precisão de equações que predizem a taxa metabólica de repouso, demonstrando a necessidade de aprimorar métodos de estimação de taxa metabólica de repouso em mulheres pós-menopáusicas com diferentes composições corporais.

Palavras-chave: Metabolismo basal. Calorimetria indireta. Menopausa.

\section{NTRODUCTION}

Menopause progression leads to several changes in the hormonal profile, which exert impact on parameters related to Resting Metabolic Rate (RMR) and body composition, such as increased adipose tissue, increased central adiposity, and decreased lean mass, consequently increasing the risk of developing metabolic and cardiovascular diseases [1,2]. Thus, interventions based on the individual estimates of the energy requirements in terms of diet and exercise to determine an adequate energy balance should be recommended for health promotion in postmenopausal women [3].

Resting metabolic rate can be obtained by indirect calorimetry or predicted by different equations. Indirect calorimetry is a method by which metabolic rate is measured based on the oxygen consumption $\left(\mathrm{O}_{2}\right)$ and the production of carbon dioxide $\left(\mathrm{CO}_{2}\right)$, considering that the total $\mathrm{O}_{2}$ consumed is related to the oxidation of macronutrients and the total $\mathrm{CO}_{2}$ produced is detected during the test, allowing individual RMR measurement [4]. Although it is a reliable measurement method, indirect calorimetry is expensive, time consuming, and requires trained personnel to perform it [4].

For these reasons and due to their feasibility and low cost, predictive equations are widely used in clinical practice [5]. However, there is only one equation based on postmenopausal women characteristics [6]; most equations are based on studies that describe lean individuals and a broad age group [7]. Noteworthy, most of the existing equations are outdated and may 
not be compatible with the general population, considering that there has been an exponential increase in sedentary lifestyle and obesity, resulting in differences in body composition, which leads to changes in energetic demand [8].

Predictive equations generally consider patients' anthropometric variables such as weight, height, and age. Several studies report that when used for individuals with different levels of obesity, these equations usually overestimate RMR $[9,10]$. Recent literature investigating the applicability and reliability of the most commonly used equations, such as Harris-Benedict, Schofield, Food and Agriculture Organization of the United Nations (FAO), and Mifflin-St. Jeor, present conflicting results in different populations [11-14]. Studies evaluating elderly individuals often report an overestimation of RMR [11].

Therefore, this research is justified by the lack of studies involving postmenopausal women, the inclusion of less commonly used equations, and the conflicting available data on the efficacy and effectiveness of predictive equations when compared to more precise methods, such as indirect calorimetry, due to their importance since they are practical and inexpensive methods for clinical application.

Thus, the objective of the present study was to compare RMR values determined by indirect calorimetry to those obtained using different predictive equations in lean and obese postmenopausal women.

\section{METHODS}

Twenty-four postmenopausal women, who volunteered after seeing advertisements in local newspapers, participated in the study. Sample size calculations were performed using StatsDirect version 2.7.2 (Altrincham, United Kingdom) considering a possible sample loss of $20 \%$. All participants signed a Free and Informed Consent Form. The volunteers had been diagnosed with menopause for at least two years. They had stable body weight, were sedentary (without previous exercise experience), non-smokers, did not have cardiovascular or metabolic diseases, insulin resistance, or type 2 diabetes, and were not undergoing hormonal replacement therapy. The participants were instructed to abstain from strenuous physical activity for $24 \mathrm{~h}$ before the tests. This study was approved by the Research Ethics Committee of the Universidade Federal do Rio Grande do Sul, according to Protocol $n^{\circ} 75681$, and it was conducted in accordance with the provisions of the Declaration of Helsinki.

The participants attended the laboratory on two different occasions. The first visit consisted of instructions regarding the experimental procedures, signing the consent form, and performance of anthropometric measurements. The second visit included the determination of RMR. Participants were instructed to avoid physical activities and consumption of alcohol, caffeine, and any type of medication that could influence resting metabolism during the 24 hours preceding the test. In addition, they were instructed to sleep for at least eight hours on the night prior to the experiment and to fast for 12 hours before testing; they were allowed to drink water ad libitum. Finally, participants were told they should preferably travel to the laboratory via motorized transport to minimize energy expenditure before the evaluation.

Skinfold thickness was measured using a caliper (Cescorf, Porto Alegre, RS, Brazil). Bone diameter was determined using a plicometer (Cescorf, Porto Alegre, RS, Brazil). The waist circumference was measured using a metal anthropometric tape (Sanny, São Bernardo do Campo, São Paulo, Brazil). Weight and height were measured using a scale with attached stadiometer (model OS180, Urano, Canoas, RS, Brazil). The marking of the anatomical landmarks and the skinfold measurements were performed according to the 
recommendations of the International Society for the Advancement of Kineanthropometry (ISAK) [15]. Body composition, fat mass, muscle mass, residual mass, bone mass, and skin mass were obtained based on the following variables: (1) body mass; (2) height; (3) skinfolds (triceps, subscapular, biceps, iliac crest, supraspinatus, abdominal, medial thigh, and calf); (4) perimeters (head, arm, thorax, waist, upper thigh, medial thigh, calf, hip, forearm, and ankle); and (5) specific osteometric measurements [14-16]. All measurements were performed by three different ISAK level anthropometrists with an estimated technical error of less than or equal to $1 \%$. Body Mass Index (BMI) was calculated as body weight/height ${ }^{2}$, and the participants were classified as lean and overweight individuals according to the recommendations of the Institute of Medicine [17].

All indirect calorimetry tests were performed between 07:30 am and 09:30 am in a room with controlled temperature $\left(25^{\circ} \mathrm{C}\right)$, light, and sound.

The protocol consisted of a 20-min rest in supine position, followed by a 40 -min of respiratory gas analysis using a breath-by-breath gas exchange analysis with a breathing mask connected to the pre-calibrated computerized gas analyzer (MedGraphics Cardiorespiratory Diagnostic Systems, Saint Paul, Minnesota, United States, CPX-D model) to measure the oxygen uptake $\left(\mathrm{VO}_{2}\right)$ and carbon dioxide output $\left(\mathrm{VCO}_{2}\right)$.

The period before reaching a plateau in oxygen consumption was discarded, and the RMR was calculated using the mean values of $\mathrm{VO}_{2}$ and $\mathrm{VCO}_{2}$ (L/minutes) for each participant. Two experienced researchers determined the plateau. Values of $\mathrm{kcal} /$ day were obtained using the equation proposed by Weir [18]: [(3.9 XVO $\left.{ }_{2}\right)$ $\left.+\left(1.1 \times \mathrm{VCO}_{2}\right)\right]$ to obtain oxygen consumption per minute; the results were then multiplied by 1440 to obtain total oxygen consumption in 24 hours.
The resting metabolic rate values obtained by indirect calorimetry were compared with the values obtained using the following equations: Harris and Benedict in 1984 [3], Arciero et al. [6], De Lorenzo et al. [12], Luhrmann \& Neuhaeuser Berthold [13], Institute of Medicine (IOM) [17], Berstein et al. [19], FAO [20], Fredix et al. [21], Harris \& Benedict 1919 [22], Henry \& Rees [23], Huang et al. [24], Johnstone et al. [25], Korth et al. [26], Lazzer et al. [27], Livingston [28], Mifflin et al. [29], Muller et al. [30], Owen et al. [31], and the two equations proposed by Schofield et al. [32]. The equations are shown in detail in Table 1.

The data normal distribution was verified by the Shapiro-Wilk test, and the homoscedasticity of the variances was evaluated by the Levene test. The predictive equations were compared with indirect calorimetry using the Bland-Altman method [33]. The Student's t-test for paired sample was used to compare each equation with indirect calorimetry; the Student's $t$-test for independent samples was used to compare the same equation between the groups. Correlations between RMR determined by indirect calorimetry and predictive equations were calculated using the Pearson's correlation coefficient; $p<0.05$ was considered as the level of statistical significance. Data analyses were carried out using the Statistical Package for Social Sciences (SPSS Inc, Chicago, Illinois, United States), version 18.0 for Windows, and the results were presented as mean \pm standard deviation.

RE S U L T S

The participants' characteristics are shown in Table 2. All anthropometric measurements, except for bone mass, showed a statistically significant difference between the groups.

Tables 3 and 4 present the RMR values obtained by indirect calorimetry and by the 
Table 1. Predictive Equations used in the present study.

\begin{tabular}{|c|c|c|}
\hline Authors & Population & Equation \\
\hline Arciero et al. [6] & $\mathrm{N}=75 \mathrm{~F}$ & $7.8 \times \mathrm{BM}+4.7 \times \mathrm{HM}-39.5 \times \mathrm{MS}+143.5$ \\
\hline Berstein et al. [19] & $N=202(154 \mathrm{~F})$ & $7.48 \times \mathrm{BM}-0.42 \times \mathrm{HCM}-3 \times \mathrm{AGE}+844$ \\
\hline Berstein et al. [19] (+FFM) & $\mathrm{N}=202(154 \mathrm{~F})$ & $19.02 \times \mathrm{FFM}+3.72 \times \mathrm{AM}-1.55 \times \mathrm{AGE}+236.7$ \\
\hline De Lorenzo et al. [12] & $N=320(193 \mathrm{~F})$ & $46.322 \times \mathrm{BM}+15.744 \times \mathrm{HCM}-16.66 \times \mathrm{AGE}+944$ \\
\hline FAO (AGE >60 years) $[20]$ & $\mathrm{N}=11.000$ & $8.7 \times \mathrm{BM}-25 \times \mathrm{HM}+865$ \\
\hline FAO (AGE >60 years) [20] & $N=11.000$ & $9.2 \times \mathrm{BM}+637 \times \mathrm{HM}-302$ \\
\hline Fredix et al. [21] & $\mathrm{N}=40(22 \mathrm{~F})$ & $1641+10.7 \times \mathrm{BM}-9.0 \times \mathrm{AGE}-203 \times 2$ \\
\hline Harris \& Bennedict (1919) [22] & $\mathrm{N}=333(103 \mathrm{~F})$ & $\mathrm{BM} \times 9.5634+\mathrm{HCM} \times 1.8496-\mathrm{AGE} \times 4.6756+655.0955$ \\
\hline Harris \& Bennedict (1984) [3] & $\mathrm{N}=337(169 \mathrm{~F})$ & $9.247 \times \mathrm{BM}+3.098 \times \mathrm{HCM}-4.33 \times \mathrm{AGE}+477.593$ \\
\hline Henry \& Rees [23] & $\mathrm{N}=10.552(4702 \mathrm{~F})$ & $\begin{array}{l}0.0342 \times \mathrm{BM}+2.1 \times \mathrm{HM}+0.0486 \text { (30 to } 60 \text { years }) \\
0.0356 \times \mathrm{BM}+1.76 \times \mathrm{HM}+0.0448 \text { (60 + years) }\end{array}$ \\
\hline Huang et al. [24] & $N=1.088(759 \mathrm{~F})$ & $\begin{array}{l}10.158 \times \mathrm{BM}+3.933 \times \mathrm{HCM}-1.44 \times \mathrm{AGE}+273.821 \times \mathrm{SEX}+ \\
60.655\end{array}$ \\
\hline Huang et al. [24] (+FFM) & $\mathrm{N}=1.088(759 \mathrm{~F})$ & $\begin{array}{l}14.118 \times \mathrm{FFM}+9.367 \times \mathrm{AM}-1.515 \times \mathrm{AGE}+220.863 \times \mathrm{SEX}+ \\
521.995\end{array}$ \\
\hline Institute of Medicine [17] & $\mathrm{N}=405(240 \mathrm{~F})$ & $247-2.67 \times A G E+401.5 \times B M+8.6 \times A M$ \\
\hline Johnstone et al. [25] (+FFM) & $\mathrm{N}=150(107 \mathrm{~F})$ & $\begin{array}{l}14.118 \times \mathrm{FFM}+9.367 \times \mathrm{AM}-1.515 \times \mathrm{AGE}+220.863 \times \mathrm{SEX}+ \\
521.995\end{array}$ \\
\hline Korth et al. [26] & $\mathrm{N}=104(54 \mathrm{~F})$ & $90.2 \times F F M+31.6 \times A M-12.2 \times A G E+1613$ \\
\hline Korth et al. [26] (+FFM) & $\mathrm{N}=104(54 \mathrm{~F})$ & $41.5 \times \mathrm{BM}+35.0 \times \mathrm{HCM}+1107.4 \times \mathrm{SEX}-19.1 \times \mathrm{AGE}-1731.2$ \\
\hline Lazzer et al. [27] & $N=346(182 \mathrm{~F})$ & $108.1 \times \mathrm{FFM}+1231$ \\
\hline Lazzer et al. [27] (+FFM) & $\mathrm{N}=346(182 \mathrm{~F})$ & $0.042 \times \mathrm{BM}+3.619 \times \mathrm{HM}-2.678 \mathrm{C}$ \\
\hline Livingston et al. [28] & $N=655(356 \mathrm{~F})$ & $0.067 \times \mathrm{FFM}+0.046 \times \mathrm{AM}+1.568$ \\
\hline Luhrmann \& Neuhaeuser Berthold [13] & $\mathrm{N}=355(225 \mathrm{~F})$ & $248 \times$ BM$^{0.43356}-\mathrm{AGE}(5.09)$ \\
\hline Mifflin et al. [29] & $\mathrm{N}=498(248 \mathrm{~F})$ & $9.99 \times \mathrm{BM}+6.25 \times \mathrm{HCM}-4.92 \times \mathrm{AGE}+166 \times \mathrm{SEX}-161$ \\
\hline Mifflin et al. [29] (+FMM) & $\mathrm{N}=498(248 \mathrm{~F})$ & $19.7 \times \mathrm{FFM}+413$ \\
\hline Muller et al. [30] & $\mathrm{N}=2528(1501 \mathrm{~F})$ & $0.047 \times \mathrm{BM}-0.01452 \times \mathrm{AGE}+1.009 \times \mathrm{SEX}+3.21$ \\
\hline Muller et al. [30] (+FFM) & $\mathrm{N}=2528(1501 \mathrm{~F})$ & $\begin{array}{l}0.05192 \times \mathrm{FFM}+0.04036 \times \mathrm{AM}+0.869 \times \mathrm{SEX}-0.01181 \times \mathrm{AGE} \\
+2.992\end{array}$ \\
\hline Muller et al. [30] (+BMl>30) & $\mathrm{N}=2528(1501 \mathrm{~F})$ & $0.05 \times \mathrm{BM}-0.01586 \times \mathrm{AGE}+1.103 \times \mathrm{SEX}+2.924$ \\
\hline Muller et al. [30] (+BMl>30 +FFM) & $\mathrm{N}=2528(1501 \mathrm{~F})$ & $\begin{array}{l}0.05685 \times \mathrm{FFM}+0.04022 \times \mathrm{AM}+0.808 \times \mathrm{SEX}-0.01402 \times \mathrm{AGE} \\
+2.818\end{array}$ \\
\hline Muller et al. [30] (+BMl=25-30) & $\mathrm{N}=2528(1501 \mathrm{~F})$ & $0.04507 \times \mathrm{BM}-0.01553 \times \mathrm{AGE}+1.006 \times \mathrm{SEX}+3.407$ \\
\hline Muller et al. [30] (+BMl=25-30 +FFM) & $\mathrm{N}=2528(1501 \mathrm{~F})$ & $\begin{array}{l}0.03776 \times \mathrm{BM}+0.03013 \times \mathrm{AM}+0.93 \times \mathrm{SEX}-0.01196 \times \mathrm{AGE} \\
+3.928\end{array}$ \\
\hline Owen et al. [31] & $\mathrm{N}=104(44 \mathrm{~F})$ & $\mathrm{BM} \times 7.18+795$ \\
\hline Owen et al. [31] (+FFM) & $\mathrm{N}=104(44 \mathrm{~F})$ & $19.7 \times \mathrm{FFM}+334$ \\
\hline Schofield et al. [32] (AG=30-60) & $\mathrm{N}=7173(2364 \mathrm{~F})$ & $0.034 \times \mathrm{BM}+3.538$ \\
\hline Schofield et al. [32] (AG>60) & $\mathrm{N}=7173(2364 \mathrm{~F})$ & $0.038 \times \mathrm{BM}+2.755$ \\
\hline Schofield et al. [32] (+BM +HM +AG=30-60) & $\mathrm{N}=7173(2364 \mathrm{~F})$ & $0.034 \times \mathrm{BM}+0.006 \times \mathrm{HM}+3.53$ \\
\hline Schofield et al. [32] (+BM +HM +ID > 60) & $\mathrm{N}=7173(2364 \mathrm{~F})$ & $0.033 \times \mathrm{BM}+1.917 \times \mathrm{HM}+0.074$ \\
\hline
\end{tabular}

Note: AGE: Age in years; AM: Adipose Mass (kg); FFM: Fat-Free Mass (kg); HM: Height (meters); HCM: Height (centimeters); SEX: 0 for females; BM: Body Mass (kg); BMI: Body Mass Index; F: Number of females; MS: Menopause Status.

predictive equations for the lean and overweight groups, respectively. There was no difference in the values obtained by indirect calorimetry between the groups. Nevertheless, there was 
Table 2. Participants' characteristics $(\mathrm{N}=24)$.

\begin{tabular}{lccccc}
\hline \multirow{2}{*}{ Characteristics } & \multicolumn{2}{c}{ Lean Group $(\mathrm{n}=12)$} & & \multicolumn{2}{c}{ Overweight Group $(\mathrm{n}=12)$} \\
\cline { 2 - 3 } \cline { 5 - 6 } Age (years) & Mean & 58.40 & 6.8 & Mean & SD \\
Body Mass $(\mathrm{kg})^{*}$ & 56.76 & 4.2 & 57.68 & 5.2 \\
Height $(\mathrm{cm})$ & 158.13 & 4.6 & 76.53 & 6.2 \\
BMI $\left(\mathrm{kg} / \mathrm{m}^{2}\right)^{*}$ & 22.71 & 1.6 & 159.26 & 4.3 \\
Fat-Free Mass $(\mathrm{kg})^{*}$ & 35.57 & 3.8 & 30.23 & 2.9 \\
Adipose Mass $(\mathrm{kg})^{*}$ & 21.19 & 2.7 & 46.12 & 4.7 \\
Muscle Mass $(\mathrm{kg})^{*}$ & 20.17 & 2.8 & 30.41 & 5.5 \\
Residual Mass $(\mathrm{kg})^{*}$ & 5.97 & 1.3 & 27.48 & 3.0 \\
Skin Mass $(\mathrm{kg})^{*}$ & 2.97 & 0.2 & 8.20 & 1.5 \\
Bone Mass $(\mathrm{kg})$ & 6.46 & 0.7 & 3.44 & 0.2 \\
Waist circumference $(\mathrm{cm})^{*}$ & 75.05 & 4.3 & 7.00 & 1.1 \\
Sum of Skinfolds $(\mathrm{mm})^{*}$ & 129.68 & 23.2 & 87.70 & 8.9 \\
\hline
\end{tabular}

Note: *Significantly different between groups.

SD: Standard Deviation; BMI: Body Mass Index.

difference in the RMR calculated values between the groups for all equations used. In the lean group, the following equations did not show a significant statistical difference when compared to indirect calorimetry: FAO, Fredix, Lazzer, and Schofield. However, only the Berstein, Berstein + Fat-Free Mass (FFM) and Owen + FFM equations were significantly different when compared to indirect calorimetry for the overweight group.

Therefore, the Bland-Altman method was used to compare each predictive equation with indirect calorimetry in both groups (Tables 3 and 4), allowing the identification of the five most adequate equations. The Fredix equation was the most accurate for the lean participants, with a difference of $1.7 \%$. The Lazzer equation showed a difference of $3.2 \%$. The FAO and the Schofield equations ( 1 and 2 ) showed a difference within the range from 5 to 8 percent $(5.8 \%, 7.7 \%$ and $7.1 \%$, respectively). The Huang, Henry, and IOM equations were the most accurate for the overweight individuals, when compared to indirect calorimetry with differences of $0.2 \%$, $-0.5 \%$, and $-0.5 \%$, respectively. The Arciero and IOM equations showed a difference of $1 \%$.

\section{DISCUSSION}

In the present study, RMR values were determined by indirect calorimetry in lean and overweight postmenopausal women, and the results were compared with the values obtained using different predictive equations. The main finding is that the differences in body composition in postmenopausal women affect the accuracy of equations that predict the resting metabolic rate, such as reported in other studies with different populations [14,24]. Although indirect calorimetry did not differ between the groups, surprisingly, the calculated RMR showed difference between lean and overweight women for all equations.

The equations commonly used in clinical practice for nutritional assessment of postmenopausal women are usually extrapolated since these equations were developed based on the evaluation of young individuals. Menopause causes changes in body composition that may cause overweight, and the literature on the efficacy of predictive equations corroborates this finding for this population. It is worth mentioning that in the present study, different equations 
Table 3. Comparison between Indirect Calorimetry (IC) and predictive equations (kcal/day) in lean women.

\begin{tabular}{|c|c|c|c|}
\hline \multirow{2}{*}{ IC or Predictive Equation values (kcal/day) } & \multicolumn{3}{|c|}{ Lean Group ( $n=12$ ) } \\
\hline & Mean & SD & $\%$ \\
\hline Indirect calorimety & 1343.31 & 138.7 & - \\
\hline Arciero et al. [6]* & 1210.90 & 47.1 & 9.9 \\
\hline Berstein et al. [19] ${ }^{*}$ & 1026.94 & 36.5 & 26.2 \\
\hline Berstein et al. [19] $(+\mathrm{FFM})^{*}$ & 901.47 & 71.7 & 39 \\
\hline De Lorenzo et al. [12]* & 1215.43 & 62.2 & 9.6 \\
\hline FAO [20] & 1272.37 & 74.2 & 5.8 \\
\hline Fredix et al. [21] & 1316.72 & 74.8 & 1.7 \\
\hline Harris \& Bennedict [22] (1918)* & 1217.32 & 54.2 & 9.4 \\
\hline Harris and Bennedict (1984) [3]* & 1239.44 & 54.9 & 7.6 \\
\hline Henry and Rees [23] $]^{*}$ & 1213.06 & 76.7 & 9.8 \\
\hline Huang et al. [24] & 1175.02 & 54.4 & 12.9 \\
\hline Huang et al. [24] (+FFM) ${ }^{*}$ & 1134.14 & 55.7 & 16.5 \\
\hline Institute of Medicine [17] & 1214.07 & 48.4 & 9.7 \\
\hline Johnstone et al. (+FFM) [25]* & 1141.03 & 82.7 & 16 \\
\hline Korth et al. [26] ${ }^{*}$ & 1204.32 & 74.4 & 10.6 \\
\hline Korth et al. (+FFM) [26] & 1212.05 & 98.1 & 10.1 \\
\hline Lazzer et al. [27] & 1296.30 & 70.3 & 3.2 \\
\hline Lazzer et al. (+FFM) [27]* & 1176.27 & 62.7 & 12.9 \\
\hline Livingston et al. [28] ${ }^{*}$ & 1142.30 & 57.7 & 15.8 \\
\hline Luhrmann \& Neuhaeuser Berthold [13] & 1221.08 & 55.7 & 9.1 \\
\hline Mifflin et al. [29] ${ }^{*}$ & 1106.97 & 68.6 & 18.9 \\
\hline Mifflin et al. [29] (+FMM)* & 1113.63 & 74.9 & 18.4 \\
\hline Muller et al. [30]* & 1201.09 & 52.5 & 10.7 \\
\hline Muller et al. [30] (+BMl>30) & NC & NC & NC \\
\hline Muller et al. [30] (+BMl>30 +FFM) & NC & NC & NC \\
\hline Muller et al. [30] (+FFM) & 1195.00 & 52.6 & 11.3 \\
\hline Owen et al. [31]* & 1202.52 & 30.5 & 10.6 \\
\hline Owen et al. [31] (+FFM)* & 1034.63 & 74.9 & 25.6 \\
\hline Schofield et al. [32] (AG=30-60)* & 1239.29 & 79.1 & 7.7 \\
\hline Schofield et al. [32] (+BM +HM +ID > 60) & 1246.78 & 77.4 & 7.1 \\
\hline
\end{tabular}

Note: *Significantly different from indirect calorimetry.

NC: Not Calculated; FFM: Fat-Free Mass; BMI: Body Mass Index; FAO: Food and Agriculture Organization of the United Nations.

showed poor accuracy for lean participants and curiously high accuracy in the presence of overweight or obesity. These results are in agreement with the concept that the difference between the RMR measured and predicted by equations is related to the absolute values of the RMR measured [13]. In older adults, predictive equations provide a valid estimation of RMR; however, individual errors should be considered in clinical practice [13].

The most accurate equation for lean women was that proposed by Fredrix [21], which was developed based on healthy older men and women. The authors estimated a $10-20 \%$ individual error range between measured values and the predicted values, 
Table 4. Comparison between Indirect calorimetry and predictive equations (kcal/day) in overweight women.

\begin{tabular}{|c|c|c|c|}
\hline \multirow{2}{*}{ IC or Predictive Equation values (kcal/day) } & \multicolumn{3}{|c|}{ Overweight Group ( $n=12)$} \\
\hline & Mean & SD & $\%$ \\
\hline Indirect calorimetry & 1398.61 & 218.0 & \\
\hline Arciero et al. [6] & 1370.47 & 53.5 & 1.0 \\
\hline Berstein et al. [19] ${ }^{*}$ & 1176.55 & 45.2 & 16.1 \\
\hline Berstein et al. [19] (+FFM)* & 1137.67 & 87.0 & 19.6 \\
\hline De Lorenzo et al. [12] & 1441.31 & 65.2 & -4.0 \\
\hline FAO (AGE >60 years) $[20]$ & 1469.72 & 58.0 & -6.0 \\
\hline Fredix et al. [21] & 1534.80 & 70.5 & -10.3 \\
\hline Harris \& Bennedict [22] (1918) & 1411.90 & 56.3 & -2.0 \\
\hline Harris and Bennedict (1984) [3] & 1428.93 & 54.0 & -3.2 \\
\hline Henry and Rees [23] & 1390.64 & 62.5 & -0.5 \\
\hline Huang et al. [24] & 1381.39 & 63.1 & 0.2 \\
\hline Huang et al. [24] (+FFM) & 1370.62 & 71.1 & 1.0 \\
\hline Institute of Medicine [17] & 1390.61 & 49.6 & -0.5 \\
\hline Johnstone et al. [25] (+FFM) & 1440.09 & 99.3 & 3.8 \\
\hline Korth et al. [26] & 1413.06 & 61.7 & -2.0 \\
\hline Korth et al. [26] (+FFM) & 1484.56 & 121.2 & -6.7 \\
\hline Lazzer et al. [27] & 1504.43 & 74.5 & -8.2 \\
\hline Lazzer et al. [27] (+FFM) & 1446.43 & 82.3 & -4.3 \\
\hline Livingston et al. [28] & 1345.97 & 57.9 & 2.8 \\
\hline Luhrmann \& Neuhaeuser Berthold [13] & 1459.83 & 71.3 & -5.3 \\
\hline Mifflin et al. [29] & 1315.16 & 59.3 & 5.1 \\
\hline Mifflin et al. [29] (+FMM) & 1321.60 & 92.5 & 4.7 \\
\hline Muller et al. [30] & 1425.54 & 67.0 & -2.9 \\
\hline Muller et al. [30] (+FFM) & 1410.71 & 57.2 & -2.3 \\
\hline Muller et al. [30] (+BMl>30) & 1410.17 & 54.5 & -1.9 \\
\hline Muller et al. [30] (+BMl>30 +FFM) & 1416.77 & 65.8 & -1.9 \\
\hline Owen et al. [31] & 1344.51 & 44.3 & 2.9 \\
\hline Owen et al. [31] (+FFM)* & 1242.60 & 92.5 & 10.9 \\
\hline Schofield et al. [32] (AG=30-60) & 1466.64 & 50.1 & -5.8 \\
\hline Schofield et al. [32] (+BM +HM +AG=30-60) & 1352.96 & 133.0 & 2.5 \\
\hline
\end{tabular}

Note: *Significantly different from calorimetry.

FFM: Fat-Free Mass; SD: Standard Deviation; FAO: Food and Agriculture Organization of the United Nations.

considering that individuals' energy needs could only be measured individually in this population. Other commonly used equations, such as FAO [20] and Schofield et al. [32], were considered to be accurate without statistical difference when compared to indirect calorimetry. Santos et al. [34] reported high RMR estimation accuracy for the FAO equation and poor accuracy for the Schofield equation in climacteric stage women. However, their study included lean and overweight women in the same group, which could explain the divergent results found in this study.

The Mifflin-St. Jeor equation has been shown to be adequate to estimate RMR in non-obese individuals [35], and in obese and overweight individuals with different characteristics [36]. The Mifflin-St. Jeor equation 
was derived from data collected from a sample that included a wide variety of ages and body compositions [29]. A recent study evaluating non-obese and sedentary postmenopausal women demonstrated that predictive equations overestimate RMR, showing that the FAO equation has the highest overestimation of RMR, and that the Mifflin-St. Jeor equation had the greatest accuracy [11]. These findings are contrary to those of the present study, considering that in this study, postmenopausal women were analyzed separately according to their $\mathrm{BMI}$, and the predictive equations were evaluated including muscle mass. The overweight postmenopausal women results indicate that the predictive equations provide reasonable results to estimate $R M R$, but for lean postmenopausal women the equations generally underestimate RMR. The opposite phenomena has been described for data from older and overweight women, and only the FAO and Schofield equations underestimated RMR, while the other equations provided an adequate estimate of RMR in lean elderly women [13]. However, the present study included both lean and overweight women, and the Bland-Altman method was used to better understand how different equations estimate RMR, considering the differences in body composition in this population. These methodological variations could explain the divergent results.

Noteworthy, for overweight postmenopausal women both the Huang equation [24], which is derived from obese elderly patients, and the equation proposed by Arciero [6], developed for postmenopausal women showed the best accuracy. The Berstein equation for obese women, Owen's equation, and the IOM equation, which include overweight and obesity factors, produced RMR results different from those measured by indirect calorimetry. Although, in the present study, most of the predictive equations showed a difference in RMR estimation below $\pm 5 \%$ for the overweight group, Luhrmann et al. [13] reported that the
FAO equation overestimated RMR in lean and overweight elderly women. The authors stated that the differences between the predicted and the measured RMR depended on the absolute values of the RMR measured and that predictive equations are specific for the population from which they were derived. This hypothesis is reinforced by Schusdziarra et al. [37], who argued that different equations provide accurate estimates in older and obese individuals. These authors added that although the equations are valid for group analysis, prediction is generally invalid for individual evaluations. Currently used equations provided an unreliable estimate in postmenopausal women and a less accurate estimate in lean women. Therefore, for a more accurate RMR estimate in postmenopausal women, the use of predictive equations should consider the individual characteristics. Furthermore, these equations do not provide an accurate estimate, which reinforces the need to develop a specific predictive equation for postmenopausal women, considering body composition, especially BMI. In addition, based on results obtained and on the results from previous studies [11,34], a careful validation of RMR predictive equations in the South American population still remains a perspective for future studies.

Indirect calorimetry is considered a precise method to measure resting metabolism rate and can be used to determine the amount of kcal used in 24 hours, i.e. twenty-four hour energy expenditure [38]. It is worth mentioning that in the present study the body composition measurements were made according to the multicomponent ISAK protocol [15], which results in a more accurate assessment of muscular and adipose tissue. Since muscle tissue is commonly regarded as the main determinant of RMR [39], it is accepted that interindividual differences in body composition are not sufficient to explain the total variance in RMR [40]. However, it is important to consider the difference in methodologies when comparing data from the present study with those of 
previous studies involving RMR estimation and body composition in different populations.

In conclusion, differences in body composition in postmenopausal women affect the accuracy of equations that predict resting metabolic rate. Although the indirect calorimetry values were not different between the groups, the RMR estimated using the predictive equations was significantly different between the lean and overweight groups for all equations. The equations proposed by Fredix, FAO, and Schoefield provided an accurate estimate for lean women, whereas most of the predictive equations showed good accuracy for the overweight group, and the Huang and Arciero equations were the most accurate in the present study. Considering the importance of accurate RMR estimation in terms of health promotion strategies for this population, the results obtained reinforce that in order to obtain a more accurate estimation of RMR in postmenopausal women, the use of predictive equations should consider their nutritional status and body composition parameters, such as BMI.

\section{CONTRIBUTORS}

RB CARTERI contributed to the experimental design of this study, patient selection, experiment applicability evaluation, data analysis, and manuscript preparation and writing. M FELDMANN and $\mathrm{AL}$ LOPES contributed to data analysis and manuscript preparation and writing. JS GROSS and RL KRUGER contributed to the collection of anthropometric and indirect calorimetry data and general data analysis. A REISCHAK-OLIVEIRA supervised the research project and contributed to the experimental design by reviewing and supervising all stages of conception and the procedures of the study.

\section{REFERENCES}

1. Santoro N, Chervenak JL. The menopause transition. Endocrinol Metab Clin North Am. 2004;33(4):627-36.
2. Fearon IM, Faux SP. Oxidative stress and cardiovascular disease: Novel tools give (free) radical insight. J Mol Cell Cardiol. 2009;47(3):372-81.

3. Roza AM, Shizgal HM. The Harris Benedict equation reevaluated: Resting energy requirements and the body cell mass. Am J Clin Nutr. 1984;40(1):168-82.

4. Ferrannini E. The theoretical bases of indirect calorimetry: A review. Metabolim. 1988;37(3):287-301.

5. Reeves MM, Capra S. Variation in the application of methods used for predicting energy requirements in acutely ill adult patients: A survey of practice. Eur J Clin Nutr. 2003;57(12):1530-5.

6. Arciero PJ, Goran MI, Gardner AM, Ades PA, Tyzbir RS, Poehlman ET. A practical equation to predict resting metabolic rate in older females. J Am Geriatr Soc. 1993;41(4):389-95.

7. Weijs PJ. Validity of predictive equations for resting energy expenditure in US and Dutch overweight and obese class I and II adults aged 18-65 y. Am J Clin Nutr. 2008;88(4):959-70.

8. Frankenfield DC, Rowe WA, Smith JS, Cooney RN. Validation of several established equations for resting metabolic rate in obese and nonobese people. J Am Diet Assoc. 2003;103(9):1152-9.

9. Dobratz JR, Sibley SD, Beckman TR, Valentine BJ, Kellogg TA, Ikramuddin S, et al. Predicting energy expenditure in extremely obese women. JPEN J Parenter Enteral Nutr. 2007;31(3):217-27.

10. Frankenfield D, Roth-Yousey L, Compher C. Comparison of predictive equations for resting metabolic rate in healthy nonobese and obese adults: A systematic review. J Am Diet Assoc. 2005;105(5):775-89.

11. Bonganha $V$, Libardi CA, Santos CF, De Souza GV, Conceicao MS, Chacon-Mikahil MP, et al. Predictive equations overestimate the resting metabolic rate in postmenopausal women. J Nutr Health Aging. 2013;17(3):211-4.

12. De Lorenzo A, Tagliabue A, Andreoli A, Testolin G, Comelli M, Deurenberg P. Measured and predicted resting metabolic rate in Italian males and females, aged 18-59 y. Eur J Clin Nutr. 2001;55(3):208-14.

13. Luhrmann PM, Neuhaeuser Berthold M. Are the equations published in literature for predicting resting metabolic rate accurate for use in the elderly? J Nutr Health Aging. 2004;8(3):144-9.

14. Krüger RL, Lopes $A L$, Gross JS, Macedo RCO, Teixeira BC, Oliveira ÁR. Validation of predictive equations for basal metabolic rate in eutrophic and obese subjects. Rev Bras Cineantropom Desempenho Hum. 2015;17(1):73-81.

15. Marfell-Jones $M$, Olds T, Stewart A, Carter L. International Standards for anthropometric 
assessment. Potchefstroom: North-West University; 2006.

16. Lopes AL, Sant' Ana RT, Baroni BM, Cunha GdS, Cunha GS, Radaelli R, et al. Perfil antropométrico e fisiológico de atletas brasileiros de "rugby". Rev Bras Educ Fís Esporte. 2011;25(3):387-95.

17. Trumbo P, Schlicker S, Yates AA, Poos M. Dietary reference intakes for energy, carbohydrate, fiber, fat, fatty acids, cholesterol, protein and amino acids. J Am Diet Assoc. 2002;102(11):1621-30.

18. Weir JB. New methods for calculating metabolic rate with special reference to protein metabolism. J Physiol. 1949;109(1-2):1-9.

19. Bernstein RS, Thornton JC, Yang MU, Wang J, Redmond AM, Pierson RN Jr., et al. Prediction of the resting metabolic rate in obese patients. Am J Clin Nutr. 1983;37(4):595-602.

20. World Health Organization. Energy and protein requirements. Geneva: WHO; 1985.

21. Fredrix EW, Soeters PB, Deerenberg IM, Kester $A D$, von Meyenfeldt MF, Saris WH. Resting and sleeping energy expenditure in the elderly. Eur J Clin Nutr. 1990;44(10):741-7.

22. Harris JA, Benedict FG. A biometric study of human basal metabolism. Proc Natl Acad Sci USA. 1918;4(12):370-3.

23. Henry CJ. Basal metabolic rate studies in humans: Measurement and development of new equations. Public Health Nutrition. 2005;8(7A):1133-52.

24. Huang KC, Kormas N, Steinbeck K, Loughnan G, Caterson ID. Resting metabolic rate in severely obese diabetic and nondiabetic subjects. Obes Res. 2004;12(5):840-5.

25. Johnstone AM, Rance KA, Murison SD, Duncan JS, Speakman JR. Additional anthropometric measures may improve the predictability of basal metabolic rate in adult subjects. Eur J Clin Nutr. 2006;60(12):1437-44.

26. Korth O, Bosy-Westphal A, Zschoche P, Gluer CC, Heller M, Muller MJ. Influence of methods used in body composition analysis on the prediction of resting energy expenditure. Eur J Clin Nutn. 2007;61(5):582-9.

27. Lazzer S, Agosti F, Resnik M, Marazzi N, Mornati D, Sartorio A. Prediction of resting energy expenditure in severely obese Italian males. J Endocrinol Invest. 2007;30(9):754-61.

28. Livingston EH, Kohlstadt I. Simplified resting metabolic rate-predicting formulas for normalsized and obese individuals. Obes Res. 2005;13(7):1255-62.

29. Mifflin MD, St Jeor ST, Hill LA, Scott BJ, Daugherty SA, Koh YO. A new predictive equation for resting energy expenditure in healthy individuals. Am J Clin Nutr. 1990;51(2):241-7.

30. Muller MJ, Bosy-Westphal A, Klaus S, Kreymann G, Luhrmann PM, Neuhauser-Berthold M, et al. World Health Organization equations have shortcomings for predicting resting energy expenditure in persons from a modern, affluent population: Generation of a new reference standard from a retrospective analysis of a German database of resting energy expenditure. Am J Clin Nutr. 2004;80(5):1379-90.

31. Owen OE, Kavle E, Owen RS, Polansky M, Caprio S, Mozzoli MA, et al. A reappraisal of caloric requirements in healthy women. Am J Clin Nutr. 1986;44(1):1-19.

32. Schofield WN. Predicting basal metabolic rate, new standards and review of previous work. Hum Nutr Clin Nutr. 1985;39(Suppl.1):5-41.

33. Bland JM, Altman DG. Statistical methods for assessing agreement between two methods of clinical measurement. Lancet. 1986;1(8476):307-10.

34. Santos RD, Suen VM, Marchini JS, lannetta O. What is the best equation to estimate the basal energy expenditure of climacteric women? Climacteric. 2011;14(1):112-6.

35. Frankenfield DC. Bias and accuracy of resting metabolic rate equations in non-obese and obese adults. Clin Nutr. 2013;32(6):976-82.

36. Douglas CC, Lawrence JC, Bush NC, Oster RA, Gower BA, Darnell BE. Ability of the Harris Benedict formula to predict energy requirements differs with weight history and ethnicity. Nutr Res. 2007;27(4):194-9.

37. Schusdziarra V, Wolfschlager K, Hausmann M, Wagenpfeil S, Erdmann J. Accuracy of resting energy expenditure calculations in unselected overweight and obese patients. Ann Nutr Metabol. 2014;65(4):299-309.

38. Haugen HA, Melanson EL, Tran ZV, Kearney JT, Hill JO. Variability of measured resting metabolic rate. Am J Clin Nutr. 2003;78(6):1141-5.

39. Ravussin E, Swinburn BA. Metabolic predictors of obesity: Cross-sectional versus longitudinal data. Int J Obes. 1993;17(Suppl.3):S28-31.

40. Muller MJ, Bosy-Westphal A, Kutzner D, Heller M. Metabolically active components of fat-free mass and resting energy expenditure in humans: Recent lessons from imaging technologies. Obes Rev. 2002;3(2):113-22.
Received: August 30, 2016

Final version: January 13, 2017

Approved: July 10, 2017 
